\title{
Pengaruh Brand Image, Customer Engagement, dan Brand Reputation Terhadap Kinerja UMKM Dimediasi Keunggulan Bersaing
}

\author{
Tiffany Valencia Wong ${ }^{1}$, Rosdiana Sijabat ${ }^{2}$ \\ ${ }^{1}$ Universitas Pelita Harapan \\ The Plaza Semanggi, Jl. Jend. Sudirman No.50, Jakarta, Indonesia \\ ${ }^{2}$ Universitas Katolik Indonesia Atma Jaya \\ Jl. Jenderal Sudirman No. 51, Jakarta, Indonesia \\ e-mail: ${ }^{1} 01619200010 @$ student.uph.edu, ${ }^{2}$ rosdiana.sijabat@atmajaya.ac.id
}

\begin{tabular}{llll}
\hline Informasi Artikel Diterima: 04-01-2022 Direvisi: 13-01-2022 & Disetujui: 23-01-2022 \\
\hline
\end{tabular}

\begin{abstract}
Abstrak
Pandemi Covid-19 berimbas Usaha Mikro, Kecil dan Menengah (UMKM) yang berdampak terhadap berbagai sektor. Menurut literatur yang digunakan, diketahui jika kinerja UMKM dapat ditingkatkan dengan mengacu pada faktor brand image, customer engagement, brand reputation, dan keunggulan bersaing. Penelitian ini bertujuan untuk mengetahui pengaruh brand image, customer engagement, dan brand reputation terhadap kinerja UMKM melalui keunggulan bersaing. Penelitian ini merupakan penelitian kausal dengan populasi adalah UMKM yang berada di pulau Jawa. Teknik yang digunakan adalah simple random sampling, yakni seluruh populasi memiliki hal yang sama untuk dijadikan sebagai responden penelitian. Sampel penelitian merupakan 105 UMKM. Penelitian ini merupakan penelitian SEM-PLS dengan menggunakan bantuan software SmartPLS. Hasil penelitian menunjukkan bahwa brand image dan customer engagement memiliki pengaruh positif yang siginifikan terhadap keunggulan bersaing. Brand reputation tidak memiliki pengaruh terhadap keunggulan bersaing. Customer engagement dan keunggulan bersaing memiliki pengaruh positif yang siginifikan terhadap kinerja UMKM. Brand image dan brand reputation tidak memiliki pengaruh terhadap kinerja UMKM. UMKM dapat memanfaatkan customer engagement untuk meningkatkan keunggulan bersaing, yang pada akhirnya akan meningkatkan kinerjanya, perlu adanya evaluasi terhadap brand image dan reputation yang diterapkan oleh UMKM, dan juga UMKM dapat menyadari jika brand image dan reputation merupakan sebuah modal yang dapat meningkatkan kinerjanya.
\end{abstract}

Kata Kunci: Brand Image; Customer Engagement ; Brand Reputation ; Keunggulan Bersaing; Kinerja UMKM

\begin{abstract}
Covid-19 pandemic had an impact on every sector including Micro, Small and Medium Enterprises (MSMEs). According to the literature used, it is known that the performance of MSMEs can be improved by referring to the factors of brand image, customer engagement, brand reputation, and competitive advantage. This study aims to determine the effect of brand image, customer engagement, and brand reputation on the performance of MSMEs in competitive advantage. This research is causal research with the population is MSMEs on the Java island. The technique used is simple random sampling, which means the entire population has the same thing to be used as research respondents. The research sample is 105 SMEs. This research is a SEM-PLS research using SmartPLS software.The results showed that brand image and customer engagement had a significant positive effect on competitive advantage. Brand reputation had no influence on competitive advantage. Customer engagement and competitive advantage had a significant positive influence on the performance of MSMEs. Brand image and brand reputation had no influence on the performance of MSMEs. MSMEs can take advantage of customer engagement to increase competitive advantage, which in turn will improve their performance, it is necessary to evaluate the brand image and reputation applied by MSMEs, and MSMEs can realize that brand image and reputation is a capital that can improve its performance.
\end{abstract}

Keywords: Brand Image; Customer Engagement; Brand Reputation; Competitive Advantage; MSME Performance

\section{Pendahuluan}

Pandemi Corona Virus Disease 2019

(Covid-19) semenjak kasus pertamanya di Indonesia pada Maret 2020 telah membuat perekonomian di Indonesia menjadi tidak stabil. Beraneka kebijakan tekah diterapkan oleh pemerintah Indonesia, dimulai 
dari Pembatasan Sosial Berskala Besar (PSBB) dan Pemberlakukan Pembatasan Kegiatan Masyarakat (PPKM) untuk meredam tingkat penyebaran Covid19, namun di lain sisi hal ini membuat perekonomian di Indonesia sendiri menjadi terpuruk. Dari data Badan Pusat Statistik (BPS), diketahui bahwa tingkat pertumbuhan ekonomi Indonesia pada tahun 2020 Kuartal I dan II konsumsi dan eknomi di Indonesia mengalami penurunan. Akibat dari pandemi Covid19 selain dirasakan oleh ekonomi makro juga berimbas pada ekonomi mikro di Indoensia. Usaha Mikro, Kecil dan Menengah (UMKM) berada dalam kondisi gawat secara ekonomi dan menjadi ancaman besar untuk perekonomian nasional. Sejak dimulainya Pandemi Covid-19, sebanyak 2600 UMKM terkena dampak negatif yang menyebabkan perekonomian Indonesia turun drastis. Mempertimbangkan UMKM adalah penyerap tenaga kerja (97\% dari total tenaga kerja yang ada) dan penggerak ekonomi domestik terbesar (menghimpun sampai dengan $60,4 \%$ dari total investasi) dalam beberapa dekade terakhir, maka diperlukan suatu strategi terukur dan terencana agar UMKM dapat memperbaiki kinerjanya.

Kinerja usaha merupakan salah satu ukuran pencapaian suatu usaha yang diperoleh melalui keseluruhan kegiatan produksi dan pemasaran yang berasal dari organisasi usaha (Fauni et al., 2017). Dalam mengukur kinerja perusahaan, ukuran finansial tidak cukup untuk menuntun dan mengevaluasi perjalanan perusahaan melalui yang kompetitif. Indikator ini merupakan "lagging indicator" yang secara negatif mencerminkan nilai yang dibuat atau dihilangkan oleh berbagai tindakan manajer selama periode pelaporan yang lalu (Utami, 2017). Parameter kinerja suatu perusahan berhubungan dengan skala kesuksesan yang dapat diraih oleh perusahaan tersebut. Karena efisiensi bersifat multidimensi, indikator kinerja nonkeuangan perlu dikembangkan dan diterapkan (Ramadhani et al., 2017). Kepuasan pelanggan, pelebaran pasar, nilai mutu produk, eskalasi sumber daya manusia, keunggulan dan kontribusi sosial merupakan cakupan dari kinerja non-finansial (Utami, 2017), yang mana ukuran tersebut yang akan digunakan dalam penelitian ini.

Menurut Binh et al., (2017) untuk meningkatkan kinerja perusahaan dibutuhkan peranan brand image untuk mengubah perilaku pembelian konsumen secara tidak langsung. Niat membeli yang positif melekat pada brand image yang kuat. Brand image terbukti memiliki pengaruh terhadap kinerja UMKM, semakin baik brand image yang dimiliki suatu UMKM maka semakin baik juga kinerja usaha yang dimilikinya (Musa et al., 2016). Selain brand image, faktor lain yang tidak kalah penting dalam membangun kinerja UMKM adalah customer engagement. Customer engagement memegang peranan penting dalam suatu perusahaan, dimana dalam menjadikan konsumen terlibat merupakan bagian dari strategi pemasaran suatu perusahaan (Wahyuni \& Sara, 2020), dan pada akhirnya akan mencapai tujuan perusahaan yaitu meningkatkan loyalitas pelanggan. Customer engagement mewakili keadaan psikologis seseorang yang ditandai dengan tingkat intensitas tertentu yang memainkan peran sentral dalam proses keterlibatan pelanggan (Harimurti \& Suryani, 2019). Faktor berikutnya yang diteliti dalam penelitian ini adalah brand reputation yang diartikan sebagai sumber permintaan dan daya tarik yang selalu ada, citra kualitas unggul dan nilai tambah membenarkan harga premium (Susanti, 2020). Menurut Bailey (2005) dalam Maemunah (2019) reputasi perusahaan adalah pemangku kepentingan perusahaan yang akan mampu meningkatkan kinerja perusahaan. Reputasi perusahaan merupakan aset terpenting, bahkan hingga tidak ternilai dalam membangun kinerja perusahaan. Reputasi perusahaan dapat menjaga hubungan dengan pelanggan sehingga kinerja perusahaan akan lebih baik (Maemunah, 2019).

Dengan adanya ketiga faktor tersebut, diharapkan suatu UMKM dapat meningkatkan kinerjanya dengan meningkatkan keunggulan bersaing. Keunggulan bersaing merupakan bentuk strategi yang digunakan untuk mendukung kelangsungan usaha dan meningkatkan kinerja usaha (Wulandari et al., 2017). Maka dari itu, untuk meningkatkan kinerja UMKM, perusahaan perlu meningkatkan keunggulan bersaing. Keunggulan bersaing dapat ditingkatkan dengan memanfaatkan brand image (Panda et al., 2019), customer engagement (Wahyuni \& Sara, 2020), dan brand reputation (Sihite et al., 2016). Dari seluruh variabel eksogen pada penelitian ini (brand image, customer engagement, dan brand reputation), semua diasumsikan juga memiliki pengaruh terhadap keunggulan bersaing.

Berdasarkan penjelasan di atas, maka peneliti akan melakukan penelitian mengenai brand image, customer engagement, dan customer brand reputation serta pengaruhnya terhadap kinerja perusahaan dengan melalui keunggulan bersaing. Penelitian ini dipilih karena membahas mengenai topik yang dirasa krusial untuk saat ini yang mana nantinya hasil penelitian ini dapat diharapkan dapat menjadi solusi. Selain itu, penelitian ini menarik karena hipotesis penelitian yang diujikan terbilang masih jarang, terkhususnya pada subjek penelitian di Indonesia.

\section{Kinerja Perusahaan}

Kinerja usaha merupakan salah satu ukuran pencapaian suatu usaha yang diperoleh melalui keseluruhan kegiatan produksi dan pemasaran yang berasal dari organisasi usaha. Pengukuran sampai mana sebuah produk yang dihasilkan oleh suatu bisnis dapat dilakukan menggunakan konsep kinerja usaha (Fauni et al., 2017). Ketika mengukur kinerja perusahaan, indikator keuangan saja tidak cukup 
untuk mengevaluasi perusahaan dan mengarah ke pasar yang kompetitif selangkah demi selangkah. Ukuran tersebut adalah "lagging indicator" yang secara negatif mencerminkan nilai yang diciptakan atau dimusnahkan oleh tindakan manajer selama periode pelaporan terbaru (Utami, 2017).

\section{Brand Image}

Brand image didefinisikan oleh Aaker (2009) sebagai rangkaian keterlibatan merek yang tersimpan di benak konsumen. Sedangkan Keller (2011) dalam Binh et al., (2017) brand image terkait dengan kognisi merek, itu dibuat dalam ingatan konsumen melalui keterlibatan merek. Brand image juga merupakan persepsi konsumen tentang suatu merek, hal itu mengarah pada kesimpulan konsumen tentang informasi mengenai merek tersebut (He et al., 2013). Graeff (1970) dalam Binh et al., (2017) menyiratkan bahwa brand image mirip dengan citra pribadi konsumen ketika konsumen mengasosiasikan diri dengan merek. Panda et al., (2019) mengkonseptualisasikan brand image sebagai warisan, kualitas layanan dan kepercayaan dan menyelidiki hubungannya dengan keunggulan bersaing yang diukur dengan kepuasan pelanggan. Temuan dari penelitian tersebut menunjukkan bahwa brand image memainkan peran penting dalam tingkat kepuasan pelanggan yang mana hal ini menyatakan jika pengelolaan brand image yang baik dapat membuat suatu usaha memiliki keunggulan dalam bersaing.

Naatu (2016) dalam penleitiannya mengatakan jika branding adalah komponen penting dalam pemasaran yang menentukan keberhasilan suatu organisasi. Dari Naatu (2016) juga ditunjukan bahwa faktor branding dianggap penting karena merupakan variabel yang memiliki pengaruh positif yang signifikan terhadap keunggulan kompetitif.

Soim et al., (2016) mengungkapkan bahwa brand image memiliki pengaruh yang signifikan terhadap keputusan pembelian. Musa et al., (2016) dalam penelitiannya mengatakan brand image terbukti memiliki pengaruh terhadap kinerja UMKM. Semakin baik nilai brand image yang berhasil dicapai suatu UMKM maka kinerja usaha yang dimilikinya juga semakin baik.

$\mathrm{H}_{1}$ : Brand image pada UMKM berpengaruh positif terhadap keunggulan bersaing.

$\mathrm{H}_{4} \quad$ : Brand image pada UMKM berpengaruh positif terhadap kineja perusahaan.

\section{Customer Engagement}

Customer engagement adalah salah satu kunci keberhasilan bisnis yang merupakan bagian dari konsep pemasaran relasional. Customer engagement merupakan hubungan komunikasi atau interaksi yang terjalin antara pemangku kepentingan eksternal seperti pelanggan dan produsen atau perusahaan melalui berbagai saluran (Islam et al., 2020). Customer engagement dalam proses pemasaran dapat dilakukan secara offline yaitu interaksi langsung dengan produsen atau melalui online menggunakan media sosial (Chen et al., 2020). Salah satu indikator keberhasilan customer engagement adalah adanya peningkatan konsumsi dan permintaan terhadap suatu produk atau jasa (Islam et al., 2020).

Wahyuni dan Sara (2020) menyatakan keterlibatan pelanggan berpengaruh positif terhadap kinerja inovasi. Gupta et al., (2017) menyatakan customer engagement yang dimiliki perusahaan akan mengarah pada peningkatan keunggulan kompetitifnya.

Musa et al., (2016) menyatakan jika customer engagement memiliki pengaruh terhadap kinerja UMKM. Wahyuni dan Sara (2020) dalam penelitiannya menunjukkan bahwa customer engagement berpengaruh positif terhadap kinerja dari sisi inovasi.

$\mathrm{H}_{2}$ : Customer engagement pada UMKM berpengaruh positif terhadap keunggulan bersaing.

$\mathrm{H}_{5}$ : Customer engagement pada UMKM berpengaruh positif terhadap kineja perusahaan.

\section{Brand Reputation}

Brand reputation digambarkan sebagai sumber daya perusahaan untuk mempengaruhi penciptaan nilai dan keuntungan yang dapat menghasilkan penciptaan keunggulan kompetitif yang berkelanjutan dan meningkatkan nilai intrinsik perusahaan (Almeida \& Coelho, 2017). Berdasarkan semua definisi di atas, dapat disimpulkan bahwa brand reputation adalah citra perusahaan berdasarkan fitur atau interaksi antara konsumen dan perusahaan yang dapat merangsang keunggulan kompetitif yang berkelanjutan dan meningkatkan nilai intrinsik suatu perusahaan.

Sihite et al., (2016) menyatakan bahwa ada hubungan positif dan dampak reputasi perusahaan dalam memperoleh keunggulan bersaing. Makalew et al., (2016) yang menyatakan jika terdapat pengaruh signifikan reputasi merek terhadap keunggulan bersaing.

Maemunah (2019) membuktikan bahwa kinerja bisnis dipengaruhi positif dan signifikan oleh reputasi perusahaan. Musa et al., (2016) menyatakan jika terdapat dari hubungan brand reputation terhadap kinerja UMKM.

$\mathrm{H}_{3} \quad$ : Brand reputation pada UMKM berpengaruh positif terhadap keunggulan bersaing

$\mathrm{H}_{6} \quad$ : Brand reputation pada UMKM berpengaruh positif terhadap kineja perusahaan.

\section{Keunggulan Bersaing}

Keunggulan bersaing menurut Porter (1986) adalah kemampuan suatu perusahaan untuk mencapai manfaat ekonomi di atas pendapatan yang dapat dicapai oleh pesaing di pasar dalam industri yang sama. Perusahaan yang memiliki keunggulan 
kompetitif selalu memiliki kemampuan untuk memahami struktur pasar yang berubah dan mampu memilih strategi pemasaran yang efektif. Studi yang dilakukan lebih lanjut menetapkan strategi generik Porter diklasifikasikan ke dalam tiga kategori, yaitu kepemimpinan biaya, diferensiasi, dan fokus (Tairas et al., 2016).

Wulandari et al., (2017) membuktikan bahwa kinerja bisnis dipengaruhi positif dan signifikan oleh keunggulan bersaing. Wardhani et al., (2021) keunggulan kompetitif memiliki pengaruh positif terhadap kinerja perusahaan.

$\mathrm{H}_{7}$ : Keunggulan bersaing pada UMKM berpengaruh positif terhadap kineja perusahaan.

\section{Model Penelitian}

Berdasarkan tujuh hipotesis yang telah diuraikan pada bagian sebelumnya, maka dapat digambarkan model penelitian sebagai berikut:

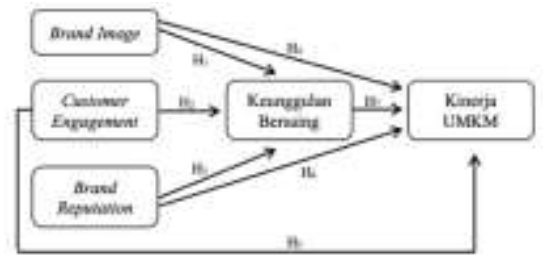

Gambar 1. Model Penelitian

\section{Metode Penelitian}

Berdasarkan tujuan studi, jenis penelitian yang akan dilakukan merupakan pengujian hipotesis untuk mengetahui hubungan korelasi maupun hubungan sebab akibat antar variabel penelitian. Oleh karena itu, penelitian ini tergolong dalam jenis penelitian kausal. Dikarenakan 5 dari 8 provinsi yang memiliki sebaran pelaku UMKM di Indonesia pada tahun 2021 diketahui berada di pulau Jawa dan karena adanya efisiensi waktu dan kemudahan dalam mendapatkan sampel, maka populasi pada penelitian ini adalah pelaku UMKM yang berada di pulau Jawa. Teknik yang diterapkan adalah simple random sampling, yakni seluruh populasi memiliki kesamaan dalam suatu hal untuk dijadikan sebagai responden penelitian.

Jumlah indikator yang digunakan pada penelitian ini adalah sebanyak 21 indikator yang mencakup lima variabel. Populasi penelitian ini adalah UMKM sehingga penelitian ini bersifat tidak diketahui secara pasti. Oleh karena hal tersebut, dalam menentukan jumlah sampel yang populasinya tidak diketahui, peneliti menggunakan metode yang digunakan Hair et al., (2017), yaitu indikator x 5 hingga 10, sehingga dalam penelitian ini dapat ditentukan jumlah sampel sebesar 105 UMKM. Kuesioner yang terkumpul diolah menggunakan SEM PLS.

\section{Karakteristik Responden}

Subjek pada penelitian ini merupakan 105 responden yang merupakan pelaku UMKM di pulau Jawa. Pada tahap ini, peneliti akan melakukan uji deskriptif yang bertujuan untuk mengetahui karakteristik responden berdasarkan jenis lokasi, jenis UMKM, dan badan hukum UMKM. Adapun hasil dari tanggapan responden adalah sebagai berikut:

Tabel 1. Profil Responden

\begin{tabular}{|c|c|c|c|}
\hline \multirow{2}{*}{ Indikator } & \multirow{2}{*}{ Keterangan } & \multicolumn{2}{|c|}{ Total } \\
\hline & & $\mathbf{F}$ & $\%$ \\
\hline \multirow{6}{*}{$\begin{array}{c}\text { Lokasi } \\
\text { UMKM }\end{array}$} & Banten & 3 & $2.86 \%$ \\
\hline & DI Yogyakarta & 8 & $7.62 \%$ \\
\hline & DKI Jakarta & 45 & $42.86 \%$ \\
\hline & Jawa Barat & 18 & $17.14 \%$ \\
\hline & Jawa Tengah & 22 & $20.95 \%$ \\
\hline & Jawa Timur & 9 & $8.57 \%$ \\
\hline \multirow{18}{*}{$\begin{array}{c}\text { Jenis } \\
\text { Usaha } \\
\text { UMKM }\end{array}$} & Total & 105 & $100.00 \%$ \\
\hline & Bisnis Kuliner & 39 & $37.14 \%$ \\
\hline & Bisnis Fashion & 14 & $13.33 \%$ \\
\hline & Bisnis Pendidikan & 2 & $1.90 \%$ \\
\hline & Bisnis Otomotif & 4 & $3.81 \%$ \\
\hline & Bisnis Agribisnis & 11 & $10.48 \%$ \\
\hline & Bisnis Tour \& & 5 & $476 \%$ \\
\hline & Bisnis Produk & 10 & \\
\hline & Kreatif & 10 & $9.52 \%$ \\
\hline & Bisnis Teknologi & 2 & \\
\hline & Internet & & $1.90 \%$ \\
\hline & Bisnis Kecantikan & 6 & $5.71 \%$ \\
\hline & Bisnis Event & 4 & \\
\hline & Organizer & 4 & $3.81 \%$ \\
\hline & Bisnis Jasa & 2 & \\
\hline & Kebersihan & 2 & $1.90 \%$ \\
\hline & $\begin{array}{l}\text { Bisnis Kebutuhan } \\
\text { Anak }\end{array}$ & 6 & $5.71 \%$ \\
\hline & Total & 105 & $100.00 \%$ \\
\hline \multirow{6}{*}{$\begin{array}{l}\text { Badan } \\
\text { Hukum } \\
\text { UMKM }\end{array}$} & BUMDes & 11 & $10.48 \%$ \\
\hline & $\mathrm{CV}$ & 38 & $36.19 \%$ \\
\hline & Koperasi & 17 & $16.19 \%$ \\
\hline & Yayasan & 3 & $2.86 \%$ \\
\hline & Belum Terdaftar & 36 & $34.29 \%$ \\
\hline & Total & 105 & $100.00 \%$ \\
\hline
\end{tabular}

Sumber: Hasil Pengolahan Data (2021)

Dari tabel 1, didapatkan bahwa mayoritas responden sebanyak 45 UMKM (42.86\%) berada di DKI Jakarta, mayoritas 39 UMKM $(37,14 \%)$ bergerak pada bidang kuliner, dan mayoritas 38 UMKM $(36,19 \%)$ berbadan hukum CV.

\section{Hasil dan Pembahasan \\ Hasil Pengujian Convergent Validity}

Penentuan keputusan dalam uji convergent validity dipenuuhi dengan cara membandingkan nilai loading factor, yang mana jika nilai loading factor lebih besar dari 0,70 maka dianggap sangat baik. Ada juga pendapat yang mengatakan jika lebih besar dari 0,60 sudah dianggap cukup (Hair et al., 2017). Dari hasil pengujian yang dilakukan, didapati hasil sebagai berikut: 
Tabel 2. Nilai Outer Model

\begin{tabular}{cc}
\hline Item Pertanyaan & Nilai Convergent Validity \\
\hline BI1 & 0.759 \\
BI2 & 0.879 \\
BI3 & 0.888 \\
CE1 & 0.779 \\
CE2 & 0.823 \\
CE3 & 0.758 \\
CE4 & 0.773 \\
CE5 & 0.736 \\
CE6 & 0.711 \\
BR1 & 0.894 \\
BR2 & 0.898 \\
BR3 & 0.817 \\
KB1 & 0.718 \\
KB2 & 0.960 \\
KB3 & 0.913 \\
K1 & 0.777 \\
K2 & 0.750 \\
K3 & 0.811 \\
K4 & 0.761 \\
K5 & 0.208 \\
K6 & 0.198 \\
\hline
\end{tabular}

Sumber: Hasil Pengolahan Data (2021)

Dari tabel 2, diketahui terdapat 2 item pertanyaan yang memiliki nilai di bawah 0,60 , yaitu K5 dan K6 yang mana berarti pada pengujian berikutnya akan dihilangkan.

\section{Hasil Pengujian Discriminant Validity}

Dalam uji discriminant validity, pengambilan keputusan dilakukan melalui uji Heteroit-Monoroit Ratio (HTMT), yang mana jika nilai korelasi HTMT lebih rendah dari 0,9, maka variabel dikatakan valid. (Wiyono, 2020).

Tabel 3. Hasil Uji Discriminant Validity

\begin{tabular}{|c|c|c|c|c|c|}
\hline & BI & $C E$ & $B R$ & KB & K \\
\hline \multicolumn{6}{|l|}{ Brand Image } \\
\hline $\begin{array}{l}\text { Brand } \\
\text { Reputation }\end{array}$ & 0.831 & & & & \\
\hline $\begin{array}{l}\text { Customer } \\
\text { Engagement }\end{array}$ & 0.758 & 0.750 & & & \\
\hline $\begin{array}{l}\text { Keunggulan } \\
\text { Bersaing }\end{array}$ & 0.751 & 0.675 & 0.602 & & \\
\hline $\begin{array}{l}\text { Kinerja } \\
\text { UMKM }\end{array}$ & 0.850 & 0.803 & 0.724 & 0.833 & \\
\hline
\end{tabular}

Sumber: Hasil Pengolahan Data (2021)

Dari tabel 3, hasil pengujian discriminant validity menjukkan hasil nilai HTMT seluruh variabel memiliki nilai yang lebih rendah dari 0.9 , sehingga dapat disimpulkan jika seluruh variabel pada penelitian ini dikatakan valid.

\section{Hasil Pengujian Composite Reliability}

Pengambilan keputusan dalam uji composite reliability dilakukan dengan melihat pada nilai composite reliability yang didapat. Jika nilai composite reliability > 0,70, maka dapat dikatakan jika variabel tersebut reliabel (Wiyono, 2020).

Tabel 4. Hasil Uji Composite Reliability

\begin{tabular}{lc}
\hline \multicolumn{1}{c}{ Variabel } & $\begin{array}{c}\text { Nilai Composite } \\
\text { Reliability }\end{array}$ \\
\hline Brand Image & 0.878 \\
Brand Reputation & 0.904 \\
Customer Engagement & 0.894 \\
Keunggulan Bersaing & 0.902 \\
Kinerja UMKM & 0.860 \\
\hline Sumber: Hasil Pengolahan Data (2021)
\end{tabular}

Dari tabel 4, diketahui jika seluruh variabel memiliki nilai composite reliability yang lebih besar dari 0,70, sehingga dapat disimpulkan jika seluruh variabel pada penelitian ini dikatakan reliabel.

\section{Nilai $R$-Square $\left(\mathbf{R}^{2}\right)$}

Nilai $R$-Square $\left(\mathrm{R}^{2}\right)$ menjadi tolak ukur dalam melakukan evaluasi model struktural bagi masing-masing variabel laten endogen, yang berperan sebagai kekuatan dalam memprediksi model struktural tersebut. Suatu evaluasi inner model dapat dikatakan memiliki model struktural yang kuat jika nilai $R$-Square $\left(\mathrm{R}^{2}\right)>0,50$, dan dapat dikatakan lemah jika nilai $R$-Square $\left(\mathrm{R}^{2}\right)<0,50$ (Wiyono, 2020). Adapun hasil pengukuran model struktural sebagai berikut:

Tabel 5. Nilai $R$-Square Masing-Masing Variabel

\begin{tabular}{lc}
\hline Variabel & Nilai $\boldsymbol{R}$-Square \\
\hline Keunggulan Bersaing & 0.422 \\
Kinerja UMKM & 0.654 \\
\hline
\end{tabular}

Sumber: Hasil Pengolahan Data (2021)

Dari tabel 5, diketahui jika variabel keunggulan bersaing memiliki nilai $R$-Square sebesar 0,422 atau $42,2 \%$. Hasil tersebut menjelaskan jika keunggulan bersaing dipengaruhi sebesar $42,2 \%$ oleh brand image, customer engagement, dan brand reputation, sedangkan sisanya sebesar $57,8 \%$ dipengaruhi oleh variabel lain yang tidak diteliti dalam penelitian ini. Sedangkan nilai $R$-Square yang didapat oleh variabel kinerja UMKM adalah sebesar 0,654 atau $65,4 \%$. Hasil tersebut menjelaskan jika kinerja UMKM dipengaruhi sebesar $65,4 \%$ oleh brand image, customer engagement, brand reputation, dan keunggulan bersaing, sedangkan sisanya sebesar 34,6\% dipengaruhi oleh variabel lain yang tidak diteliti dalam penelitian ini.

\section{Nilai $Q$-Square $\left(\mathbf{Q}^{2}\right)$}

Setelah melihat masing-masing nilai $R$ Square dari setiap variabel, maka langkah selanjutnya adalah mengetahui nilai $Q$-Square untuk mengevaluasi structural model penelitian. Evaluasi ini dilakukan untuk merepresentasikan sebuah hasil penelitian dari cross validation. Adapun sebuah model akan dikatakan memiliki predictive relevance, 
jika nilai $Q$-Square $\left(\mathrm{Q}^{2}\right)>0$, dan jika nilai $\mathrm{Q}$-Square $\left(\mathrm{Q}^{2}\right)<0$, maka model penelitian kurang memiliki predictive relevance (Wijoyo, 2020).

$$
\begin{array}{ll}
\mathrm{Q}^{2} & =1-\left(1-\mathrm{R}_{1}^{2}\right)\left(1-\mathrm{R}_{2}^{2}\right) \\
\mathrm{Q}^{2} & =1-(1-0,422)(1-0,654) \\
\mathrm{Q}^{2} & =1-(0,578)(0,346) \\
\mathrm{Q}^{2} & =1-0,199 \\
\mathrm{Q}^{2} & =0,801
\end{array}
$$

Nilai $\mathrm{Q}^{2}$ didapatkan sebesar $0,801>0$. Hal ini menunjukkan bahwa evaluasi model struktural yang telah diobservasi memiliki predictive relevance yang baik.

\section{Pengujian Hipotesis}

Pengujian hipotesis dilakukan dengan pengujian satu arah (one tailed) dengan sig. level 5\% atau 0,05 yang mana hipotesis diterima jika nilai $\mathrm{t}_{\text {statistik }}$ lebih besar dari 1,64 (Tarigan \& Septiani, 2017). Apabila nilai $t_{\text {statistik }}$ lebih besar dari 1,64 atau $\mathrm{P}_{\text {value }}$ lebih rendah dari taraf signifikansi 5\% atau 0,05 maka hasil dinyatakan signifikan (Wiyono, 2020).

\begin{tabular}{|c|c|c|c|}
\hline Path & \multicolumn{2}{|c|}{$\begin{array}{c}\text { Koefisien } \\
\text { T Statistics } \boldsymbol{P} \text { Values } \\
\end{array}$} & Keputusan \\
\hline $\begin{array}{l}\text { Brand } \\
\text { Image } \rightarrow \\
\text { Keunggulan } \\
\text { Bersaing }\end{array}$ & 2,763 & 0,006 & $\begin{array}{c}\text { Berpengaruh } \\
\text { Signifikan }\end{array}$ \\
\hline $\begin{array}{l}\text { Brand } \\
\text { Image } \rightarrow \\
\text { Kinerja } \\
\text { UMKM }\end{array}$ & 1,947 & 0,043 & $\begin{array}{c}\text { Berpengaruh } \\
\text { Signifikan }\end{array}$ \\
\hline $\begin{array}{l}\text { Brand } \\
\text { Reputation } \\
\rightarrow \\
\text { Keunggulan } \\
\text { Bersaing }\end{array}$ & 0,577 & 0,564 & $\begin{array}{c}\text { Tidak } \\
\text { Berpengaruh } \\
\text { Signifikan }\end{array}$ \\
\hline $\begin{array}{l}\text { Brand } \\
\text { Reputation } \\
\rightarrow \text { Kinerja } \\
\text { UMKM }\end{array}$ & 0,394 & 0,694 & $\begin{array}{c}\text { Tidak } \\
\text { Berpengaruh } \\
\text { Signifikan }\end{array}$ \\
\hline $\begin{array}{l}\text { Customer } \\
\text { Engagement } \\
\rightarrow \\
\text { Keunggulan } \\
\text { Bersaing }\end{array}$ & 2,091 & 0,037 & $\begin{array}{c}\text { Berpengaruh } \\
\text { Signifikan }\end{array}$ \\
\hline $\begin{array}{l}\text { Customer } \\
\text { Engagement } \\
\rightarrow \text { Kinerja } \\
\text { UMKM }\end{array}$ & 0,800 & 0,573 & $\begin{array}{c}\text { Tidak } \\
\text { Berpengaruh } \\
\text { Signifikan }\end{array}$ \\
\hline $\begin{array}{l}\text { Keunggulan } \\
\text { Bersaing } \rightarrow \\
\text { Kinerja } \\
\text { UMKM }\end{array}$ & 6,710 & 0,000 & $\begin{array}{c}\text { Berpengaruh } \\
\text { Signifikan }\end{array}$ \\
\hline
\end{tabular}

Dari hasil pengujian Bootstrapping yang dilakukan dengan menggunakan Smart PLS, maka didapati nilai path coefficients sebagai berikut:

Tabel 6. Path Coefficients
Sumber: Hasil Pengolahan Data (2021)

Gambar 2. Hasil Bootstraping

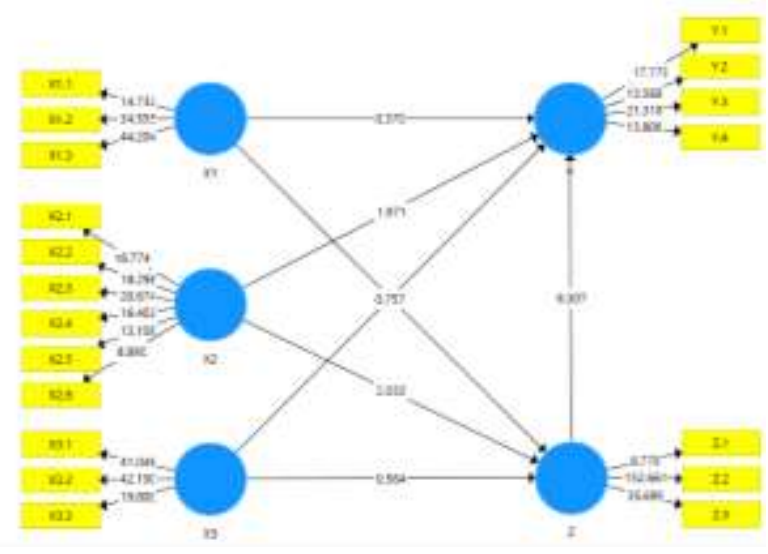

\section{Pengaruh Brand Image Terhadap Keunggulan Bersaing}

Dari hasil tabel 6, diketahui jika nilai $\mathrm{t}_{\text {statistik }}$ yang didapat (2,772) lebih besar dari 1,64 yang menjelaskan jika brand image memiliki pengaruh terhadap keunggulan bersaing. Nilai $P_{\text {values }}$ yang didapat adalah 0,006 yang memiliki nilai lebih rendah dari 5\% atau 0,05 yang menjelaskan jika pengaruh brand image terhadap keunggulan bersaing adalah signifikan. Dari hasil pengujian yang sudah dilakukan, maka dapat disimpulkan jika hipotesis 1 diterima karena brand image terbukti memiliki pengaruh positif yang siginifikan terhadap keunggulan bersaing.

Dari hasil penelitian yang dilakukan, diketahui jika brand image terbukti memiliki pengaruh positif yang siginifikan terhadap keunggulan bersaing, yang mana menunjukkan jika semakin baik brand image yang dimiliki maka semakin baik keunggulan bersaing yang dimiliki sebuah UMKM. Dari hasil tersebut, maka dapat disimpulkan jika $\mathrm{H}_{1}$ dalam penelitian ini diterima.

Hasil penelitian ini selaras dengan penelitian yang dilakukan Panda et al., (2019) yang menyatakan jika brand image memainkan peran penting dalam tingkat kepuasan pelanggan yang mana hal ini menyatakan jika pengelolaan brand image yang baik dapat membuat suatu usaha memiliki keunggulan dalam bersaing. Hasil penelitian yang sama juga dilakukan oleh Mulyono (2016) yang menyatakan jika brand image mampu memberikan pengaruh terhadap perceived value, yang mana perceived value yang dirasakan adalah penilaian keseluruhan konsumen atas utilitas layanan berdasarkan persepsi apa yang diterima dan apa yang diberikan. Hal tersebut merupakan bagian dari keunggulan bersaing mengenai kemampuan UMKM untuk melakukan pilihan yang memiliki kombinasi sesuai dengan nilai yang diminta oleh konsumen.

Penelitian lainnya yang memberikan hasil serupa dilakukan oleh Jannah et al., (2018) yang menyatakan jika brand image berpengaruh langsung 
terhadap kepuasan pelanggan. Perusahaan yang melakukan mengembangkan diferensiasi produk dengan melibatkan brand image akan dapat memberikan nilai pelayanan yang berbeda dari pesaing, yang pada akhirnya akan meningkatkan kepuasan pelanggan. Hasil penelitian tersebut selaras dengan penelitian yang dilakukan oleh Hasby et al., (2018) yang menyatakan jika brand image memiliki pengaruh terhadap keunggulan bersaing yang diwakili oleh perceived value dan loyalitas konsumen.

Brand image yang dikelola dengan baik oleh UMKM akan dapat meningkatkan aspek-aspek perilaku konsumen yang merujuk pada pengambilan keputusan pembelian hingga meningkatkan keunggulan bersaing berkelanjutan UMKM tersebut. Dengan adanya brand image pada suatu UMKM, konsumen akan dengan mudah mengenali produk UMKM kita, baik hanya mereknya saja atau hingga keunggulan yang dimilikinya, sehingga produk yang kita tawarkan selangkah lebih berpotensi akan dibeli oleh konsumen jika dibandingkan dengan produk sejenis yang memiliki citra merek yang kurang baik.

\section{Pengaruh Customer Engagement Terhadap Keunggulan Bersaing}

Dari hasil tabel 6, diketahui jika nilai $\mathrm{t}_{\text {statistik }}$ yang didapat (2,032) lebih besar dari 1,64 yang menjelaskan jika customer engagement memiliki pengaruh terhadap keunggulan bersaing. Nilai $P_{\text {values }}$ yang didapat adalah 0,043 yang memiliki nilai lebih rendah dari $5 \%$ atau 0,05 yang menjelaskan jika pengaruh customer engagement terhadap keunggulan bersaing adalah signifikan. Dari hasil pengujian yang sudah dilakukan, maka dapat disimpulkan jika hipotesis 2 diterima karena customer engagement terbukti memiliki pengaruh positif yang siginifikan terhadap keunggulan bersaing.

Dari hasil penelitian yang dilakukan, diketahui jika customer engagement terbukti memiliki pengaruh positif yang siginifikan terhadap keunggulan bersaing, yang mana menunjukkan jika semakin baik customer engagement yang dimiliki maka semakin baik keunggulan bersaing yang dimiliki sebuah UMKM. Dari hasil tersebut, maka dapat disimpulkan jika $\mathrm{H}_{2}$ dalam penelitian ini diterima.

Penelitian lainnya yang memberikan hasil serupa dilakukan oleh Wahyuni dan Sara (2020) yang bertujuan untuk mengembangkan model kinerja inovasi berdasarkan peran keterlibatan pelanggan. Penelitian tersebut memiliki hasil jika customer engagement berpengaruh positif terhadap kinerja inovasi sehingga memperoleh keunggulan dalam bersaing. Pradana (2017) dalam penelitiannya juga menyatakan jika customer engagement berpengaruh positif terhadap keunggulan bersaing.

Penelitian lainnya dilakukan oleh Okhotan et al., (2015) yang menyimpulkan jika customer engagement dapat memberikan dampak positif terhadap keunggulan bersaing. Penelitian serupa pernah dilakukan oleh Alqershi et al., (2020) yang mengatakan jika Customer Relationship Management berpengaruh signifikan terhadap keunggulan bersaing UKM. Dengan adanya CRM, organisasi akan menjadi lebih untung di pasar yang kompetitif jika mereka dapat mempertahankan pelanggan mereka yang sudah ada.

Dalam lingkungan yang sangat kompetitif, UMKM harus dapat memenuhi kebutuhan konsumen agar mereka terpuaskan sehingga terbentuklah engagement. Dari customer engagement tersebut UMKM telah berhasil memiliki basis pelanggan sebagai aset yang berharga bagi UMKM. Untuk memastikan bisnis terus bertumbuh serta profit terus didapat perusahaan di masa depan, konsumen harus berada dalam ikatan hubungan ini sehingga tidak mudah bagi pelanggan untuk berganti ke brand kompetitor dan berkontribusi bagi perusahaan untuk mendapatkan pelanggan baru.

\section{Pengaruh Brand Reputation Terhadap Keunggulan Bersaing}

Dari hasil tabel 6, diketahui jika nilai $\mathrm{t}_{\text {statistik }}$ yang didapat $(0,564)$ lebih rendah dari 1,64 yang menjelaskan jika brand reputation tidak memiliki pengaruh terhadap keunggulan bersaing. Begitupun dengan nilai $P_{\text {values }}$ yang didapat adalah 0,573 yang memiliki nilai lebih besar dari $5 \%$ atau 0,05 yang menjelaskan jika brand reputation tidak memiliki terhadap keunggulan bersaing. Dari hasil pengujian yang sudah dilakukan, maka dapat disimpulkan jika hipotesis 3 ditolak karena brand reputation terbukti tidak memiliki pengaruh positif yang siginifikan terhadap keunggulan bersaing.

Dari hasil penelitian yang dilakukan, diketahui jika brand reputation terbukti tidak memiliki pengaruh yang siginifikan terhadap keunggulan bersaing, yang mana menunjukkan jika semakin baik brand reputation yang dimiliki maka tidak akan meningkatkan keunggulan bersaing yang dimiliki sebuah UMKM. Dari hasil tersebut, maka dapat disimpulkan jika $\mathrm{H}_{3}$ dalam penelitian ini ditolak.

Hasil penelitian ini memiliki hasil berbeda dengan penelitian yang dilakukan Sihite et al., (2016) yang menyatakan jika reputasi memiliki pengaruh terhadap keunggulan kompetitif. Dalam penelitiannya, Sihite et al., (2016) merepresentasikan reputasi menjadi peningkatan produk dan layanan, lingkungan kerja, kepemimpinan, manajemen bisnis, kompetensi, dan tanggung jawab sosial. Sarjana dan Khayati (2017) dalam penelitiannya juga menyatakan jika reputasi berpengaruh terhadap keunggulan bersaing. Goryacheva dan Kalinina (2019) menyatakan jika reputasi merupakan bagian dari keunggulan kompetitif yang membentuk stereotip persepsi di masyarakat, yang terdiri dari penilaian terhadap bentuk dan metode mempromosikan organisasi 
Oktaviani et al., (2021) dalam penelitiannya juga menyatakan jika reputasi yang dimiliki oleh sebuah perusahaan dapat mempengaruhi secara positif dan signifikan terhadap keunggulan bersaing yang dimilikinya. Hal ini berbeda dengan yang peneliti lakukan dimana reputasi direpresentasikan menjadi alat mengembangkan citra merek, penilaian yang baik dari publik, dan komunikasi yang menciptakan dan mempertahankan reputasi yang berkelanjutan.

Reputasi dibangun selama bertahun-tahun secara konsisten untuk mendapatkan sesuatu yang mampu dinilai oleh masyarakat dimana hal ini tentunya tidak dapat dicapai dalam waktu singkat. Reputasi juga dapat bertahan dan sustainable karena hal-hal yang dilakukan secara konsisten. Dalam hal ini, reputasi merupakan tujuan jangka panjang yang harus dirancang suatu unit bisnis, yang mana biasanya hal ini sulit dilakukan oleh pelaku UMKM yang notabene mengutamakan tujuan jangka pendek hingga menengah. Di lain sisi, banyak pelanggan yang tidak terlalu mempedulikan reputasi UMKM, karena kebanyakan dari mereka memilih produk UMKM hanya berdasarkan faktor kualitas produk dan harga.

\section{Pengaruh Brand Image Terhadap Kinerja UMKM}

Dari hasil tabel 6, diketahui jika nilai $\mathrm{t}_{\text {statistik }}$ yang didapat $(0,370)$ lebih rendah dari 1,64 yang menjelaskan jika brand image tidak memiliki pengaruh terhadap kinerja UMKM. Begitupun dengan nilai $P_{\text {values }}$ yang didapat adalah 0,711 yang memiliki nilai lebih besar dari $5 \%$ atau 0,05 yang menjelaskan jika brand image tidak memiliki terhadap kinerja UMKM. Dari hasil pengujian yang sudah dilakukan, maka dapat disimpulkan jika hipotesis 4 ditolak karena brand image terbukti tidak memiliki pengaruh positif yang siginifikan terhadap kinerja UMKM.

Dari hasil penelitian yang dilakukan, diketahui jika brand image terbukti tidak memiliki pengaruh positif yang siginifikan terhadap kinerja UMKM, yang mana menunjukkan jika semakin baik brand image yang dimiliki maka tidak akan meningkatkan kinerja yang dimiliki sebuah UMKM. Dari hasil tersebut, maka dapat disimpulkan jika $\mathrm{H}_{4}$ dalam penelitian ini ditolak.

Hasil penelitian ini berbeda dengan penelitian yang dilakukan Musa et al., (2016) yang mendapati hasil jika brand image memiliki pengaruh terhadap kinerja UMKM. Semakin baik brand image yang dimiliki suatu UMKM maka semakin baik juga kinerja usaha yang dimilikinya. Handiyono (2017) dalam penelitiannya menyatakan jika brand image memiliki pengaruh terhadap kinerja suatu perusahaan. Kurniawan et al., (2016) dalam penelitiannya mendapati hasil jika brand image tidak memiliki pengaruh yang signifikasi terhadap keputusan pembelian. Dalam hal ini terdapat kesamaan dengan penelitian yang peneliti lakukan karena salah satu dari tujuan peningkatan kinerja UMKM adalah meningkatkan penjualan atau pembelian konsumen.

Kinerja UMKM dalam penelitian ini diukur dengan kinerja non-finansial, seperti kualitas produk, peningkatan jumlah karyawan, efsiensi internal, pengembangan produk, pertumbuhan dan tanggung jawab sosial. Dari hasil uji deskripsi yang dilakukan, diketahui jika keseluruhan indikator tersebut dinyatakan baik, sehingga dapat disimpulkan jika peningkatan kinerja tersebut terjadi tidak dikarenakan oleh citra merek yang dimiliki UMKM, atau dengan kata lain dipengaruhi oleh faktor lain, seperti peningkatan modal, kerjasama bisnis, bantuan pemerintah, dan lain-lain.

\section{Pengaruh Customer Engagement Terhadap Kinerja UMKM}

Dari hasil tabel 6, diketahui jika nilai $\mathrm{t}_{\text {statistik }}$ yang didapat (1,971) lebih besar dari 1,64 yang menjelaskan jika customer engagement memiliki pengaruh terhadap kinerja UMKM. Nilai $P_{\text {values }}$ yang didapat adalah 0,049 yang memiliki nilai lebih rendah dari $5 \%$ atau 0,05 yang menjelaskan jika pengaruh customer engagement terhadap kinerja UMKM adalah signifikan. Dari hasil pengujian yang sudah dilakukan, maka dapat disimpulkan jika hipotesis 5 diterima karena customer engagement terbukti memiliki pengaruh positif yang siginifikan terhadap kinerja UMKM.

Dari hasil penelitian yang dilakukan, diketahui jika customer engagement terbukti memiliki pengaruh positif yang siginifikan terhadap kinerja UMKM, yang mana menunjukkan jika semakin baik customer engagement yang dimiliki maka semakin baik kinerja yang dimiliki sebuah UMKM. Dari hasil tersebut, maka dapat disimpulkan jika $\mathrm{H}_{5}$ dalam penelitian ini diterima.

Hasil penelitian ini memilki keselarasan dengan penelitian yang dilakukan oleh Musa et al., (2016) yang bertujuan mengetahui hubungan customer engagement terhadap kinerja UMKM. Dari hasil penelitian yang dilakukan, didapati jika customer engagement terbukti memiliki pengaruh terhadap kinerja UMKM. Semakin baik customer engagement yang dimiliki suatu UMKM maka semakin baik juga kinerja usaha yang dimilikinya.

Wahyuni dan Sara (2020) dalam penelitiannya menyatakan jika customer engagement dapat mempengaruhi kinerja perusahaan untuk berinovasi secara positif dan signifikan. Penelitian serupa dilakukan oleh Youssef et al., (2018) menunjukkan bahwa customer engagement mengacu pada kemampuan perusahaan untuk meng-enagage pelanggan dalam memenuhi kebutuhan dinamis mereka yang pada akhirnya dapat membuat pelanggan mereka puas dan setia. Penelitian serupa dilakukan oleh Lee dan Ha (2019) yang menyatakan jika tingkat customer engagement memiliki efek 
positif pada customer response profitability dan service coordination costs, yang mana keduanya merupakan bagian dari kinerja perusahaan.

Dengan adanya customer engagement yang baik, UMKM terstimulus untuk meningkatkan kinerja UMKM-nya yang mana ini merupakan bagian dari strategi pemasaran suatu perusahaan, dan pada akhirnya akan mencapai tujuan perusahaan yaitu meningkatkan loyalitas pelanggan. Customer engagement menjadi penting bagi UMKM karena kebanyakan dari mereka masih menggunakan strategi pemasaran word of mouth, serta melakukan pengembangan bisnis yang bersifat praktis yaitu dari saran konsumennya. Hal ini diketahui dari uji deskripsi pada customer engagement yang mana pada indikator "UMKM membuka dialog dengan pelanggan" dan "UMKM membangun interaksi dengan pelanggan" memiliki nilai di atas rata-rata. Maka dapat disimpulkan, jika dialog dan interaksi UMKM dengan konsumennya dapat berlangsung dengan baik, maka konsumen akan memiliki loyalitas sehingga rela melakukan word on mouth, yang pada akhirnya UMKM akan meningkatkan kinerjanya untuk memenuhi kebutuhan pasar yang ada.

\section{Pengaruh Brand Reputation Terhadap Kinerja UMKM}

Dari hasil tabel 6, diketahui jika nilai $\mathrm{t}_{\text {statistik }}$ yang didapat $(0,757)$ lebih rendah dari 1,64 yang menjelaskan jika brand reputation tidak memiliki pengaruh terhadap kinerja UMKM. Begitupun dengan nilai $P_{\text {values }}$ yang didapat adalah 0,573 yang memiliki nilai lebih besar dari $5 \%$ atau 0,05 yang menjelaskan jika brand reputation tidak memiliki terhadap kinerja UMKM. Dari hasil pengujian yang sudah dilakukan, maka dapat disimpulkan jika hipotesis 6 ditolak karena brand reputation terbukti tidak memiliki pengaruh positif yang siginifikan terhadap kinerja UMKM.

Dari hasil penelitian yang dilakukan, diketahui jika brand reputation terbukti tidak memiliki pengaruh positif yang siginifikan terhadap kinerja UMKM, yang mana menunjukkan jika semakin baik brand reputation yang dimiliki maka tidak akan meningkatkan kinerja yang dimiliki sebuah UMKM. Dari hasil tersebut, maka dapat disimpulkan jika $\mathrm{H}_{6}$ dalam penelitian ini ditolak.

Hasil penelitian ini memiliki hasil yang serupa dengan penelitian yang dilakukan oleh Andilala et al., (2017) mendapati hasil jika reputasi tidak memiliki pengaruh terhadap kepercayaan. Penelitian serupa lainnya dilakukan oleh Prasetyo dan Widodo (2017) menyatakan jika reputasi tidak secara siginifikan dapat mempengaruhi niat beli konsumen pada suatu produk.

Hasil penelitian ini memilki perbedaan dengan penelitian yang dilakukan oleh Maemunah (2019) yang dalam penelitiannya membuktikan bahwa kinerja bisnis dipengaruhi positif dan signifikan oleh reputasi perusahaan. Dari hasil penelitian yang dilakukan, didapati jika reputasi terbukti memiliki pengaruh terhadap kinerja UMKM. Semakin baik reputasi yang dimiliki suatu UMKM maka semakin baik juga kinerja usaha yang dimilikinya. Selain itu, penelitian yang dilakukan Shi (2016) menjelaskan jika reputasi yang dimiliki oleh perusahaan dapat meningkatkan kinerjanya dari sisi keuangan.

Dalam hipotesis sebelumnya, yaitu pada $\mathrm{H}_{4}$, diketahui jika brand image terbukti tidak memiliki pengaruh terhadap kinerja UMKM. Hal ini menjadi relevan karena secara teori, reputasi merupakan bagian dari citra atau image. Dari penjelasan tersebut, dapat dipahami jika peningkatan kinerja UMKM terjadi memang tidak dikarenakan oleh citra atau reputasi merek yang dimiliki UMKM, atau dapat dipahami jika UMKM belum mampu memanfaatkan citra atau reputasi merek sebagai suatu modal penting dalam meningkatkan penjualan perusahaan sehingga dapat mendongkrak kinerjanya.

\section{Pengaruh Keunggulan Bersaing Terhadap Kinerja UMKM}

Dari hasil tabel 6, diketahui jika nilai $\mathrm{t}_{\text {statistik }}$ yang didapat $(6,307)$ lebih besar dari 1,64 yang menjelaskan jika keunggulan bersaing memiliki pengaruh terhadap kinerja UMKM. Nilai $P_{\text {values }}$ yang didapat adalah 0,000 yang memiliki nilai lebih rendah dari $5 \%$ atau 0,05 yang menjelaskan jika pengaruh keunggulan bersaing terhadap kinerja UMKM adalah signifikan. Dari hasil pengujian yang sudah dilakukan, maka dapat disimpulkan jika hipotesis 7 diterima karena keunggulan bersaing terbukti memiliki pengaruh positif yang siginifikan terhadap kinerja UMKM.

Dari hasil penelitian yang dilakukan, diketahui jika keunggulan bersaing terbukti memiliki pengaruh positif yang siginifikan terhadap kinerja UMKM, yang mana menunjukkan jika semakin baik keunggulan bersaing yang dimiliki maka semakin baik kinerja yang dimiliki sebuah UMKM. Dari hasil tersebut, maka dapat disimpulkan jika $\mathrm{H}_{7}$ dalam penelitian ini diterima.

Hasil penelitian ini memilki selaras dengan penelitian yang dilakukan oleh Wulandari et al., (2017) yang dalam penelitiannya membuktikan bahwa kinerja bisnis dipengaruhi positif dan signifikan oleh keunggulan bersaing. Dari hasil penelitian yang dilakukan, didapati jika keunggulan bersaing terbukti memiliki pengaruh terhadap kinerja UMKM. Semakin baik keunggulan bersaing yang dimiliki suatu UMKM maka semakin baik juga kinerja usaha yang dimilikinya.

Penelitian ini juga mendukung hasil penelitian yang dilakukan oleh Dewi dan Ekawati (2017) keunggulan bersaing berpengaruh positif dan signifikan terhadap kinerja pemasaran. Novitasari (2016) dalam penelitiannya juga menyatakan jika keunggulan bersaing berpengaruh positif terhadap kinerja perusahaan. Manurung et al., (2016) dalam 
penelitiannya juga menyatakan jika keunggulan bersaing berpengaruh positif signifikan terhadap kinerja bisnis.

Secara sederhana keunggulan bersaing dapat diartikan sebagai sumber dari kapabilitas unggul dari bisnis. Secara umum, sebuah perusahaan dikatakan kompetitif jika memenuhi tiga kriteria: 1) memiliki sesuatu yang tidak dimiliki pesaingnya, 2) unggul dibandingkan yang lain, dan (3) ada kelebihan yang tidak dimiliki perusahaan lain (Rinandiyana et al., 2017). Keunggulan bersaing adalah alat untuk memperoleh objek akhir bisnis yaitu meningkatkan kinerja bisnis (Wulandari et al., 2017).

\section{Kesimpulan}

Dari hasil penelitian yang dilakukan dapat disimpulkan bahwa brand image dan customer engagement memiliki pengaruh positif yang siginifikan terhadap keunggulan bersaing, sedangkan brand reputation tidak memiliki pengaruh yang siginifikan terhadap keunggulan bersaing. Brand image dan brand reputation tidak memiliki pengaruh positif yang siginifikan terhadap kinerja UMKM, sedangkan customer engagement memiliki pengaruh positif yang siginifikan terhadap kinerja UMKM. Kemudian, keunggulan bersaing terbukti memiliki pengaruh positif yang siginifikan terhadap kinerja UMKM.

Dari keseluruhan indikator pada variabel eksogen pada penelitian ini, semuanya terbukti memiliki nilai yang valid dan reliabel. Namun, terdapat dua variabel eksogen yang tidak memiliki pengaruh terhadap variabel endogen yang diujikan. Pada penelitian berikutnya, peneliti menyarankan untuk melakukan pengujian ulang dengan indikator dari teori yang berbeda yang lebih selaras dengan UMKM.

Penelitian ini memiliki keterbatasan karena tidak mengujikan UMKM menjadi beberapa sampel penelitian yang berbeda. Sehingga penelitian berikutnya dapat menguji UMKM secara terpisah, baik dari sisi jenis usaha atau tingkatan usahanya sehingga lebih dapat diketahui spesifikasinya antara variabel yang diujikan dengan perbedaan-perbedaan karakteristik UMKM.

Penelitian berikutnya dapat menggunakan variabel-variabel eksogen lain untuk diujikan dalam penelitian ini sehingga lebih diketahui faktor-faktor apa saja yang mempengaruhi kinerja UMKM, dan dapat diketahui faktor apa yang paling mendominasi sehingga dapat dijadikan saran penelitian yang lebih spesifik untuk diterapkan demi kemajuan UMKM di Indonesia.

\section{Referensi}

Aaker, D. A., \& Joachimsthaler, E. (2009). Brand Leadership: Building Assets In an Information Economy. Simon and Schuster. https://books.google.co.id/books/about/Brand_ Leadership.html?id=lfuL2aefJSsC\&redir_esc= y

Almeida, M. da G. C., \& Coelho, A. M. (2017). The Impact of Corporate Reputation in a Dairy Company. Business and Economics Journal, 08(04). https://doi.org/10.4172/21516219.1000320

Andilala, M. E. A., Bachtiar, F. A., \& Saputra, M. C. (2017). Analisis Pengaruh Harga, Persepsi Ukuran, Persepsi Reputasi, dan Kualitas Layanan Terhadap Kepercayaan Konsumen Dalam Menggunakan .... Jurnal Pengembangan Teknologi Informasi Dan Ilmu Komputer, 2(September 2017), 1638-1647. http://j-ptiik.ub.ac.id/index.php/jptiik/article/download/1542/466

Binh, L. D., Vo, T. H. G., \& Le, K. H. (2017). The impact of electronic word of mouth on brand image and buying decision: An empirical study in Vietnam tourism. International Journal of Research Studies in Management, 6(1). https://doi.org/10.5861/ijrsm.2017.1738

Chen, X., Sun, X., Yan, D., \& Wen, D. (2020). Perceived sustainability and customer engagement in the online shopping environment: The rational and emotional perspectives. Sustainability, 12(7), 1-16.

Dewi, N. M., \& Ekawati, N. W. P. (2017). Peran Keunggulan Eran Keunggulan Bersaing Dalam Memediasi Pengaruh Orientasi Pasar Terhadap Kinerja Pemasaran. E-Jurnal Manajemen Unud, 6(9), 4947-4977. https://media.neliti.com/media/publications/24 9598-peran-keunggulan-bersaing-dalammemedias-e0588528.pdf

Fauni, A. M., Rusdarti, \& Wahyudin, A. (2017). Factors Influencing The Business Performance of SMES Convections in Kudus. Journal of Economic Education, 6(2), 124-133.

Goryacheva, O., \& Kalinina, G. (2019). Reputation as a competitive advantage. Journal of Interdisciplinary Research, 9(2), 136.

Gupta, S., Pansari, A., \& Kumar, V. (2017). Global customer engagement. Journal of International Marketing, 26(1), 4-29.

Hair, J., Hollingsworth, C. L., Randolph, A. B., \& Chong, A. Y. L. (2017). An updated and expanded assessment of PLS-SEM in information systems research. Industrial Management \& Data Systems.

Harimurti, R., \& Suryani, T. (2019). the Impact of Total Quality Management on Service Quality, Customer Engagement, and Customer Loyalty in Banking. Jurnal Manajemen Dan Kewirausahaan, 21(2), 95-103. https://doi.org/10.9744/jmk.21.2.95-103

Hasby, R., Irawanto, D. W., \& Hussein, A. S. (2018). The Effect of Service Quality and Brand Image on Loyalty With Perception of Value As a Mediation Variable. Jurnal Aplikasi Manajemen, $\quad$ 16(4), 705-713. 
https://doi.org/10.21776/ub.jam.2018.016.04.1 7

He, M., Sha, Z., \& Yang, b Y. (2013). An Empirical Study on Impacts of Brand Image of Travel Agencies on Customer Purchase Intentions. Proceedings of the 2nd International Conference On Systems Engineering and Modeling, https://doi.org/10.2991/icsem.2013.70

Islam, J. U., Shahid, S., Rasool, A., Rahman, Z., Khan, I., \& Rather, R. A. (2020). Impact of website attributes on customer engagement in banking: a solicitation of stimulus-organismresponse theory. International Journal of Bank Marketing, 38(6), 1279-1303. https://doi.org/10.1108/IJBM-12-2019-0460

Jannah, E. N., Sudaryanto, \& Wulandari, G. A. (2018). Pengaruh Kualitas Layanan dan Brand Image Terhadap Loyalitas Melalui Kepuasan Pelanggan Matahari Department Store di Jember. UNEJ E-Proceding, 339-350.

Lee, K., \& Ha, B. C. (2019). The impact of customer engagement on service coordination costs in content service: the mediating effect of customer response profitability. The International Journal of Social Sciences and Humanities Invention, 6(11), 5716-5723. https://doi.org/10.18535/ijsshi/v6i11.06

Maemunah, S. (2019). the Effect of Corporate Reputation and Sustainable Innovation Strategy on Business Performance in Automotive Companies. Business and Entrepreneurial Review, 18(1), https://doi.org/10.25105/ber.v18i1.5305

Makalew, G. A., Mananeke, L., \& Tawas, H. (2016). Analisis Pengaruh Reputasi Merek, Kualitas Layanan, dan Loyalitas Nasabah Terhadap Keunggulan Bersaing (Studi Pada Nasabah Taplus Anak PT Bank Negara Indonesia (PERSERO) Tbk Kantor Cabang Utama Manado. Emba, 4(3), 531-544.

Manurung, M. T., Sugiarto, J., \& Munas, B. (2016). Membangun Keunggulan Bersaing untuk Meningkatkan Kinerja Bisnis pada Industri Kecil Menengah Tenun Ikat di Troso, Jepara. Jurnal Bisnis STRATEGI, 25.

Mulyono, H. (2016). Brand awareness and brand image of decision making on university. Jurnal Manajemen Dan Kewirausahaan, 18(2), 163173. https://doi.org/10.9744/jmk.18.2.163

Musa, H., Rahim, N. A., Azmi, F. R., Shibghatullah, A. S., \& Othman, N. A. (2016). Social Media Marketing and Online Small and Medium Enterprises Performance: Perspective of Malaysian Small and Medium Enterprises. International Review of Management and Marketing, 6(7), 1-5.

Naatu, F. (2016). Brand Building for Competitive Advantage in the Ghanaian Jewelry Industry. International Review of Management and
Marketing, 6(3), 551-558.

Novitasari, H. I. (2016). Pengaruh Supply Chain Management Terhadap Keunggulan Bersaing dan Kinerja Perusahaan (Studi Pada UKM Kerajinan Gerabah Di Kasongan). Skripsi Fakultas Ekonomi, Universitas Islam Indonesia. https://dspace.uii.ac.id/handle/123 456789/2848

Okhotan, E. A., Dharmayanti, D., \& Si, M. (2015). Pengaruh Marketing Capability Terhadap Customer Loyalty Dengan Customer Engagement Dan Competitive Advantage Sebagai Variabel Intervening Pada Indosat Ooredoo Di Surabaya. Jurnal Strategi Pemasaran, 9.

Oktaviani, Y. I., Sihite, M., \& Derriawan. (2021). Strategi Kinerja Perusahaan Dipengaruhi Inovasi, Kualitas Produk, Reputasi Perusahaan melalui Keunggulan Bersaing PT. X. Jurnal Sosial Dan Teknologi (SOS, 1(10), 287-298.

Panda, S., Pandey, S. C., Bennett, A., \& Tian, X. (2019). University brand image as competitive advantage: a two-country study. International Journal of Educational Management, 33(2), 234-251. https://doi.org/10.1108/IJEM-122017-0374

Pradana, D. W. (2017). Budaya Engagement: Pengaruhnya Terhadap Keunggulan Kompetitif Pada Sekolah Swasta Di Semarang. Ekspektra, 1 , https://doi.org/10.25139/ekt.v0i0.350

Prasetyo, S., \& Widodo, T. W. (2017). Anteseden Kepercayaan Pengguna Pada Penawaran Ecommerce Dan Konsekuensinya Terhadap Niat Beli (studi Pengguna E-commerce Provinsi Dki Jakarta). ... Management, 4(2), 1429-1436.

https://openlibrarypublications.telkomuniversit y.ac.id/index.php/management/article/view/76 0

Ramadhani, D. A., Titisari, P., \& Sayekti, Y. (2017). Penilaian Kinerja Keuangan Dan Non Keuangan Pada Kantor Keluarga Berencana Kabupaten Situbondo. Bisma, 11(2), 237. https://doi.org/10.19184/bisma.v11i2.6318

Rinandiyana, L. R., Kurniawati, A., \& Kurniawan, D. (2017). Strategi Untuk Menciptakan Keunggulan Bersaing Melalui Pengembangan, Desain, Dan Kualitas Produk (Kasus Pada Industri Pakaian Muslim Di Kota Tasikmalaya). Jurnal Ekonomi Manajemen, 2(November),

105-113. http://jurnal.unsil.ac.id/index.php/jem/article/v iew/319

Sarjana, S., \& Khayati, N. (2017). The Role of Reputation For Achieving Competitive Advantage. 36(Icbmr), 322-334. https://doi.org/10.2991/icbmr-17.2017.30

Shi, Y. (2016). Reputation, Financial Performance, and Industry Competition. Reputation, 
Financial Performance, and Industry Competition, 10(2), 1-16.

Sihite, M., Sule, E. T., Azis, Y., \& Kaltum, U. (2016). Gain Competitive Advantage Through Reputation. South East Asia Journal of Contemporary Business, Economics and Law, 10(3), 22-32.

Soim, F. M., Suharyono, \& Abdillah, Y. (2016). Pengaruh Brand Image terhadap Keputusan Pembelian (Studi pada Pembeli Kartu Perdana simPATI di Booth Telkomsel Matos). Jurnal Administrasi Bisnis, 35(1), 146-153.

Susanti, C. E. (2020). The Effect Of Brand Reputation On Brand Loyalty Through Brand Trust On Yoga Tourist Destination In Ubud, Bali, Indonesia. Journal of Critical Reviews, 7(8), 1160-1166.

Tairas, D. R., Rahman Kadir, A., \& Mardiana, R. (2016). The Influence of Strategic Leadership and Dynamic Capabilities through Entrepreneurship Strategy and Operational Strategy in Improving the Competitive Advantage of Private Universities in Jakarta, Indonesia. Scientific Research Journal (SCIRJ), IV(II), 8-18. www.scirj.org

Utami, L. R. (2017). Efek Balance Scorecard Terhadap Penentuan Strategi Perusahaan. Jurnal Bisnis Dan Ekonomi, 24(1), 62-74. https://www.unisbank.ac.id/ojs/index.php/fe3/ article/view/5564
Wahyuni, N. M., \& Sara, I. M. (2020). Market Orientation and Innovation Performance: Mediating Effects of Customer Engagement in SMEs. Journal of Economics, Business, and Accountancy Ventura, 23(1), 28-37.

Wardhani, A. P., Kusumawardhani, A., \& Ubaidillah, M. (2021). The Effect of Intangible Asset On Competitive Advantage and Firm Performance; Study on Budget Accommodation in Semarang City. Jurnal Sosial Dan Budaya Syar-I, 8(2), 383-404.

Wiyono, G. (2020). Merancang Penelitian Bisnis Dengan Alat Analisis SPSS 25 \& SmartPLS 3.2.8. UPP STIM YKPN.

Wulandari, W., Sari, R. N., \& L, A. A. (2017). Pengaruh Supply Chain Management Terhadap Kinerja Perusahaan Melalui Keunggulan Bersaing. Jurnal Ekonomi, 21(3), 462-479. https://doi.org/10.24912/je.v21i3.31

Youssef, Y. M. A., Johnston, W. J., AbdelHamid, T. A., Dakrory, M. I., \& Seddick, M. G. S. (2018). A Customer Engagement Framework for a B2B Context. Journal of Business \& Industrial Marketing, 33(1), 145-152. 